\title{
Creating an intellectual commons through open access
}

\section{Citation}

Peter Suber, Creating an intellectual commons through open access, Understanding Knowledge as a Commons: From Theory to Practice (Charlotte Hess and Elinor Ostrom 2006). A revised version of an article first presented at the Workshop on Scholarly Communication as a Commons, Bloomington, Indiana, April 1, 2004.

\section{Published Version}

http://mitpress. mit.edu/catalog/item/default.asp?ttype=2\&tid=11012

\section{Permanent link}

http://nrs.harvard.edu/urn-3:HUL.InstRepos:4552055

\section{Terms of Use}

This article was downloaded from Harvard University's DASH repository, and is made available under the terms and conditions applicable to Other Posted Material, as set forth at http:// nrs.harvard.edu/urn-3:HUL.InstRepos:dash.current.terms-of-use\#LAA

\section{Share Your Story}

The Harvard community has made this article openly available.

Please share how this access benefits you. Submit a story.

\section{Accessibility}


Peter Suber

October 13, 2004

\title{
Creating an Intellectual Commons through Open Access
}

\begin{abstract}
Open-access (OA) literature is online, free of charge, and free of most copyright and licensing restrictions. The low-hanging fruit for $\mathrm{OA}$ is literature that authors consent to distribute without payment, or for which they are paid salaries by their employers rather than royalties by their publishers. This relatively small but very important category of literature includes peer-reviewed journal articles and their preprints, the primary literature of science. In this paper I discuss the peculiarities of royalty-free literature, the conditions that lead authors to consent to OA (including authors of royalty-producing literature), and some obstacles to an OA commons that have the flavor of a tragedy of the commons.
\end{abstract}

\section{What is open access?}

"Open access" (OA) is free online access. OA literature is not only free of charge to everyone with an internet connection, but free of most copyright and licensing restrictions. OA literature is barrier-free literature produced by removing the price barriers and permission barriers that block access and limit usage of most conventionally published literature, whether in print or online. ${ }^{1}$

The physical prerequisites for $\mathrm{OA}$ are that a work be digital and reside on an internet server. The legal prerequisite for $\mathrm{OA}$ is that a work be free of copyright and licensing restrictions (statutory and contractual restrictions) that would bar OA. There are two ways to eliminate these restrictions: put the work in the public domain or obtain the copyright holder's consent for all legitimate scholarly uses, such as reading, downloading, copying, sharing, storing, printing, searching, linking, and crawling. Consenting to these uses means waiving some rights granted by copyright law. But this is compatible with retaining other rights, such as the right to block the distribution of mangled or misattributed copies. Some OA authors also retain the right to block commercial reuse. ${ }^{2}$

Obviously there is some flexibility about which rights to waive and which to retain, and even some mild intramural dispute about which rights must be waived in order to create open access. The Budapest Open Access Initiative, which made "open access" the term of art for this kind of literature (February 2002), put it this way: ${ }^{3}$

There are many degrees and kinds of wider and easier access to this literature. By 'open access' to this literature, we mean its free availability on the public internet, 
permitting any users to read, download, copy, distribute, print, search, or link to the full texts of these articles, crawl them for indexing, pass them as data to software, or use them for any other lawful purpose, without financial, legal, or technical barriers other than those inseparable from gaining access to the internet itself. The only constraint on reproduction and distribution, and the only role for copyright in this domain, should be to give authors control over the integrity of their work and the right to be properly acknowledged and cited.

The economic prerequisite for $\mathrm{OA}$ is to find the means to pay for the physical and legal prerequisites. If the work is not yet digital, then one cost is digitization. If the work is digital but not yet online, then another cost is putting it online; sometimes this is the high cost of lobbying the recalcitrant, not the negligible cost of FTP'ing a file to a web server or moving a file from a closed online directory to an open one. Permission is sometimes the least expensive part of an OA project, and sometimes the most expensive. In any case, permission is only necessary, not sufficient, to create OA.

If the OA literature is to be peer reviewed, then the cost of peer review must be added to the tab. If the OA literature is to be enhanced in other ways, for example through copy editing, reference linking, or alert services, then their costs must be added as well. Most OA resources have limited funds and focus on essentials in order to keep their costs down. Different $\mathrm{OA}$ journals draw the line between essentials and inessentials at different places, based in part on their funding and in part on cultural differences among disciplines. (For example, science journals use copy editing because so many submissions come from nonnative speakers of the language, which is seldom a factor for humanities journals.) All agree, however, that peer review is essential for scientific and scholarly journal literature.

In short, OA literature is free of charge for readers and users, but not for producers. The producers require revenue or subsidies. OA owes its origin and part of its deep appeal to the fact that publishing to the internet permits both wider dissemination and lower costs than any previous form of publishing. This revolutionary conjunction is too good to pass up. But even low costs must be recovered if OA is to be sustainable.

There are two major ways of delivering open access, and they differ in their costs and funding models.

(1) OA archives or repositories do not perform peer review, but simply make their contents freely available to users around the world. They may contain unrefereed preprints, refereed postprints, or both. Archives may contain the research output of institutions, such as universities and laboratories, or disciplines, such as physics and economics. When archives comply with the metadata harvesting protocol of the Open Archives Initiative, ${ }^{4}$ then they are interoperable and users can find their contents without knowing which archives exist, where they are located, or what they contain. There are half a dozen opensource software packages for building and maintaining OAI-compliant archives. The costs of an archive are negligible: some server space and a fraction of the time of a technician. 
(2) OA journals perform peer review and then make the approved contents freely available to the world. Their expenses consist of peer review, manuscript preparation, and server space. Of these, peer review is the most significant. But peer review is essentially editorial judgment and paper handling (or file handling). In most journals and most fields, the editors and referees who exercise editorial judgment donate their services, just like the authors. The cost of peer review, then, is limited to the costs of distributing the files to reviewers, tracking progress, nagging dawdlers, facilitating communication, and collecting data. But the costs of these essentially clerical chores are steadily decreasing as they are taken over by increasingly sophisticated software, including open-source software. ${ }^{5}$

If journals are to be OA, then they cannot cover their expenses by charging readers or their libraries. Most charge a processing fee on every accepted article to be paid by the author or the author's employer, research funder, or government. If the processing fee for an article covers all the costs of vetting and publishing it, then the journal can provide free online access to the resulting full-text article without losing money. Most OA journals waive the fee in cases of economic hardship.

The upfront funding model charges the author's sponsor for outgoing papers, not the reader's sponsor for incoming papers. It charges for dissemination, not access. In this respect it resembles the funding model for television and radio. If advertisers can pay all the costs of production, then a TV studio can broadcast a show without charging viewers. In the case of TV and radio, the model works because advertisers are willing to pay to get their message across. In the case of scholarly research articles, the model works because authors are willing to relinquish royalties in order to get their message across and a growing number of institutions that employ researchers or fund research are willing to consider the cost of dissemination to be part of the cost of research. ${ }^{6}$

We can be confident that the funding model is sustainable because it works in an industry -broadcasting- where there are far greater expenses and no tradition of creators relinquishing revenue from their work. An even more secure ground for confidence is that the true costs of peer review, manuscript preparation, and OA dissemination are much lower than the price now paid for access to published journals.

But the upfront funding model is not the only one for OA journals. It works best in fields like biomedicine where most research is funded and where the major funders are already on the record as willing to pay these fees. ${ }^{7}$ But in less prosperous fields, including the humanities, one attractive model is for university libraries to publish OA journals. The Philosophers' Imprint, for example, is a peer-reviewed journal published by the University of Michigan. ${ }^{8}$ Its motto is, "Edited by philosophers, published by librarians." Because the philosophers and librarians are already on the university payroll, the journal needn't charge processing fees. The point is that there is not just one way to cover the expenses of a peerreviewed, OA journal, and we have a long way to go before we can say that we've exhausted our cleverness and imagination. 


\section{Royalty-free and royalty-producing content}

There is already OA to some music and movies, novels and news, sitcoms and software. One day there may be much more. But these genres of content all earn royalties for their creators, which makes it very difficult to get the needed permissions for OA. Either OA will deprive the content owners of revenue or they fear that it will. There is some evidence that OA needn't interfere with revenue in these ways, and in some circumstances can even enhance it. But these are reasons for copyright holders to reconsider, not reasons to disregard their decisions. So far, most of them decide against OA. ${ }^{9}$

The focus of the OA movement is on a special category of content that does not earn royalties for its creators: peer-reviewed research articles and their preprints. Ever since the first scientific journals were founded in 1665 in London and Paris, journals have not paid authors for articles. ${ }^{10}$

What incentive do authors have to publish without payment? If there were royalty-paying journals, then authors would very likely steer their work toward them. So part of the answer is that royalty-free journals are the only game in town. ${ }^{11}$ But if that were the whole story, then over time many journals would have begun to pay authors, in order to attract the best submissions, especially today when the profits of commercial journal publishers approach $40 \%$. Moreover, if the absence of alternatives were the whole story, authors might forego royalties with resignation and write journal articles as a job obligation, like committee meetings. But this is not what we see when we look.

The more important part of the answer, then, is that authors want their work to be noticed, read, taken up, built upon, applied, used, and cited. They also want the journal's time-stamp in order to establish priority over other scientists working on the same problem. If they work at a university, this way of advancing knowledge will also advance their careers. These intangible rewards (made nearly tangible in tenure and promotion) compensate scholars for relinquishing royalties on their journal articles. It explains why they are not merely willing, but eager, to submit their articles to journals that do not pay for them, and even to journals with the temerity to ask for ownership or copyright as well.

We could say that royalty-free literature is donated literature. Authors of journal articles donate them to journals. If this term is simpler and more direct, we can use it, provided we understand that relinquishing income from journal articles is not the same as relinquishing intellectual property rights. Authors of journal articles typically do both, but with the new generation of OA journals, authors tend to retain copyright, or at least key rights, while continuing to relinquish income.

Author donation is closely connected to academic freedom. Scholars can afford to donate their journal articles because they are paid salaries by universities. Their salaries free them 
from the market, so they can write journal articles without considering what would "sell" or what would appeal to the widest audience. This frees them to be controversial, or to defend unpopular ideas, a key component of academic freedom. It also frees them to be microspecialized, or to defend ideas of interest to only a few people in the world. The same insulation frees some scholars to be obscure, and it frees others, who didn't quite get the point, to be faddish and market-driven. But because the same insulation from the market makes two important freedoms possible -open access and academic freedom-, we have good reason to resist any development that would remove this insulation and make scholars' income -through salaries or royalties- depend on the popularity of their ideas. ${ }^{12}$

The fact that scholarly journal articles are royalty-free means that scholars can consent to OA without fear of losing revenue. That's important, and decisively distinguishes them from musicians and movie-makers. The readiness of scholars to relinquish royalties is an important part of the economic basis of OA. Their resulting willingness to consent to OA is the crux of the legal basis of OA.

The royalty-free character of journal articles also means that scholars don't need the temporary monopoly of copyright in order to give them an incentive to write or to stimulate their productivity, a role for copyright often claimed for authors of royaltyproducing genres. Scholars have royalty-independent incentives for writing journal articles, and hence do not lose their incentives when they waive or transfer most of the rights that run to them under copyright law. ${ }^{13}$

The royalty-free nature of journal articles also explains why scholars would not be hurt if copyright law were dramatically reformed to restore balance between copyright holders and users. Or, to see this from the other end of the stick, publishers who pretend to speak for authors in defending the current imbalance in copyright law speak for authors of royaltyproducing literature. Authors of royalty-free literature have very different interests.

Scholars have an interest in disseminating their work to all who can make use of it. They want the widest possible audience. That is the best way to be noticed, read, used, and cited. For royalty-free literature, enlarging the sphere of fair use serves the author's interests; for royalty-producing literature, it invades the author's interests. Having relinquished royalties, authors of royalty-free literature have no need to protect a revenue stream, so they have everything to gain by consenting to OA and nothing to lose. ${ }^{14}$

In short, authors of scholarly journal articles write for impact, not for money. An even stronger way to put this point is that conventional journals that limit access to paying customers harm the interests of scholarly authors and are only attractive when they offer some compensation in prestige. This often wins the day for scholars pursuing tenure or promotion. But when OA journals have been around long enough to earn prestige in proportion to their quality, this last attraction of conventional journals will disappear. ${ }^{15}$ 
Royalty-free literature is rare. It's so rare that we should pause for a moment to appreciate just how anomalous or peculiar it is in our landscape of intellectual property. Most content is priced for users. Even most content that is free for users -like TV and radioproduces royalties for its creators. To be royalty-free, the creators must relinquish any demand for payment, even if they do not relinquish intellectual property rights. If we describe this category for intelligent people without first providing an example, we should not be surprised if they think the category is empty, or filled only with ephemera that lack market value. But the category includes the primary literature of science-peer-reviewed research articles and their preprints- and the primary texts of public law, such as statutes and judicial opinions. Despite their importance however, these are professional bodies of literature barely known to people outside the professions and their rarity causes ignorance and misunderstanding about their status. With the exception of grey literature like school homework assignments and interoffice memos, most people never encounter royalty-free literature.

In most countries, statutes and judicial opinions, like other government works, are in the public domain from birth, or are not copyrightable. ${ }^{16}$ This makes copyrightable royaltyfree literature even rarer than royalty-free literature as such. At the same time, it makes clear that scientific and scholarly research articles are easily the most significant examples of the type.

The rarity of royalty-free literature causes a couple of problems for those trying to create an intellectual commons through OA. One is that copyright rules are written to protect authors and publishers of royalty-producing genres and to protect users with fair-use claims on royalty-producing genres. Even public-domain law is focused on the expiration of rights to royalty-producing genres. Legislators and lobbyists alike tend to be heedless of the need to treat royalty-free literature separately. The result is that when royalty-free literature is copyrighted, it is regulated as if it were royalty-producing, laying needlessly onerous duties on users to seek permission for anything beyond fair use. If royalty-free literature were the subject of separate, thoughtful legislative attention, it is likely that the rules of fair use, first sale, and copyright term duration, would all differ from the standard rules for royaltyproducing genres. In this sense, royalty-free literature is collateral damage in a war over royalties and the limits on royalties. ${ }^{17}$

Another problem is that the rarity of royalty-free literature increases the difficulty of changing policy, enlisting support, and disarming objections. In my experience, most nonacademics -including policy-makers- do not realize that scholarly journals publish articles without buying them or paying the authors. So until corrected, most non-academics are not inclined to support OA, thinking it calls on authors to make a sacrifice or that it depends on abolishing or violating copyright. When they are told that journal articles are royalty-free, some see the logic of OA immediately but just as many doubt that one is telling the truth. ${ }^{18}$ 
Not all academic research literature is royalty-free. Scholars write journal articles, which are royalty-free, but also books, which are royalty-producing. They also write software, which is sometimes one and sometimes the other. OA may enlarge the audience and increase the impact for all three kinds of content, but in the case of journals there is no offsetting loss of revenue and in the case of books and software there is or may be. So the very same researcher may consent to $\mathrm{OA}$ for articles but not for books. The important distinction, then, for setting priorities in promoting $\mathrm{OA}$ is whether the content is royaltyfree or royalty-producing, not whether it is scholarly or non-scholarly.

In the worldwide effort to create an intellectual commons through $\mathrm{OA}$, we can distinguish three phases, in increasing order of difficulty. ${ }^{19}$

Phase 1: Provide OA to royalty-free literature and to all other content for which there is already permission. This includes public domain content and content for which the copyright holder already consents to OA or would consent after a little education. This is the low-hanging fruit of OA. At least the legal hurdles have been cleared. There may still technical and financial hurdles, such as digitizing print content and investing in robust delivery vehicles.

Phase 2: Provide OA to royalty-producing literature and to content for which copyright holders are not yet consenting to OA. Since OA to copyrighted content must be consensual, this will require persuasion. Copyright holders have a right to try to earn money from their content, and they have at least some grounds for believing that OA conflicts with any plan to earn money from their content. Hence, persuasion will often fail, which explains why this is higher-hanging fruit. I'll say more later about the kinds of arguments that might persuade royalty-earning authors to provide OA to their work. ${ }^{20}$

Phase 3. Enlarge and protect the public domain by rolling back copyright term extensions and assuring that federal copyright law preempts state contract or licensing law. Make permission-seeking less often necessary by establishing the first-sale doctrine for digital content and restoring fair-use rights denied by copy-protection technologies. If Phase 2 persuades copyright holders to reevaluate their interests, then Phase 3 persuades legislators to revise copyright law. Successes at Phases 1 and 2 would make Phase 3 largely unnecessary, and vice versa. Phase 3 is only higher-hanging fruit because revising copyright law in the right ways is politically unlikely and as a remedy, at best, slow, incomplete, and uncertain.

\section{Open access research literature as an intellectual commons}

Some kinds of commons depend essentially on the public domain. As we've seen, this is not true for OA research literature. The public domain is only one way to remove the permission barriers that would bar OA. Copyright-holder consent ${ }^{21}$ is just as effective and 
more frequent in practice. When we take this path, then the OA commons is not only compatible with copyright, but depends essentially on decisions made by copyright holders.

Let's focus for a moment on OA created by copyright-holder consent, when the copyright holder retains at least some rights, such as the right to act against plagiarists or to block the distribution of misattributed copies. This kind of OA literature is still owned, and its owner reserves an important right. It is nevertheless a true intellectual commons because the copyright holder has removed enough permission barriers to create freedom for all the uses that matter for legitimate scholarship. For those uses, no further permission is needed.

Two legal foundations for open access:

\begin{tabular}{|l|l|}
\hline \multicolumn{1}{|c|}{ Public domain } & \multicolumn{1}{c|}{ Copyright-holder consent } \\
\hline No owner & Owner \\
\hline No rights retained & Some rights retained \\
\hline All rights either expired or waived & $\begin{array}{l}\text { Some rights waived (permitting the uses } \\
\text { needed for free and legitimate scholarship) }\end{array}$ \\
\hline $\begin{array}{l}\text { Not always voluntary (copyright expiration } \\
\text { may be resisted; uncopyrightability may be } \\
\text { resisted) }\end{array}$ & $\begin{array}{l}\text { Always voluntary, though sometimes } \\
\text { required in exchange for a job or research } \\
\text { grant }\end{array}$ \\
\hline No permission needed for scholarly uses & $\begin{array}{l}\text { Permission already granted for scholarly } \\
\text { uses }\end{array}$ \\
\hline
\end{tabular}

In June of 2003, Martin Sabo (D-MN) introduced the Public Access to Science Act (HR 2613) to the U.S. House of Representatives. Its purpose was to take a large step toward providing $\mathrm{OA}$ to government-funded research, which constitutes the majority of the natural-science research in the United States. Its strategy was to deny copyright to all the results of government-funded research, and treat it like in-house government research. The bill was controversial and not even widely supported by friends of OA. One of the main reasons is that it chose to base OA on the public domain rather than on copyright-holder consent, needlessly alienating friends of copyright. ${ }^{22}$

But whether the legal foundation for OA lies in the public domain or copyright-holder consent, OA research literature is a commons precisely because one of these legal paths has been taken to make permission unnecessary for scholarly uses of the literature.

The OA research commons is enhanced by the fact that is non-rivalrous (or nonsubtractive). It is not diminished or depleted by use, so that any number may use it without preempting or interfering with one another. This prevents the classical form of a tragedy of the commons in which opening a common resource for use by all diminishes it for all. ${ }^{23}$ 
Note, however, that the OA commons is non-rivalrous because it is digital, not because it is OA. Even proprietary digital information with price and permission barriers firmly in place is non-rivalrous. Users don't have unpaid access to it, but paying users do not diminish it by their use, no matter how many there are.

Certain categories of intellectual property in relation to OA:

\begin{tabular}{|l|l|l|}
\hline & Rivalrous & Non-rivalrous \\
\hline Royalty-free & $\begin{array}{l}\text { Not OA because rivalrous, hence } \\
\text { non-digital }\end{array}$ & The easiest case for OA \\
\hline $\begin{array}{l}\text { Royalty- } \\
\text { producing }\end{array}$ & $\begin{array}{l}\text { Not OA because (1) rivalrous, } \\
\text { non-digital, and (2) lacking } \\
\text { copyright-holder consent }\end{array}$ & $\begin{array}{l}\text { Rarely OA because rarely } \\
\text { carries copyright-holder consent }\end{array}$ \\
\hline
\end{tabular}

The same, with examples:

\begin{tabular}{|l|l|l|}
\hline & Rivalrous & Non-rivalrous \\
\hline Royalty-free & Research articles in print & Research articles online \\
\hline $\begin{array}{l}\text { Royalty- } \\
\text { producing }\end{array}$ & Music on copy-protected CDs & Music in unprotected MP3 files \\
\hline
\end{tabular}

$\mathrm{OA}$ is not about research literature in general because some research literature is rivalrous (print journals) and some of it is royalty-producing (books). And it's not about nonrivalrous content in general because some non-rivalrous content is royalty-producing (digital music and movies) and most of the royalty-producing portion does not carry the copyright holder's consent for OA.

$\mathrm{OA}$ is about the much narrower category of content that is both non-rivalrous and royaltyfree. When I stand back, I don't know what's more remarkable, that this narrow category is non-empty or that we have not long-since succeeded in providing OA to the important literature in this category.

While the category to which OA applies seems very narrow, it can easily be generalized to the wider category of non-rivalrous content for which copyright holders can be persuaded to provide OA, either because there is no money at stake (royalty-free content), because they believe that the benefits of OA outweigh the money at stake, or because they believe that OA will actually increase net sales. ${ }^{24}$ 
We know that non-rivalrousness does not suffice to make a commons because this property is possessed even by priced, copyrighted and copy-protected digital content, the exemplar of digital enclosure.

Strictly speaking, the property of being royalty-free does not suffice either; it merely increases the chances that the copyright holder will consent to OA. But it's a fair surrogate for copyright-holder consent, since creators of royalty-free property create it voluntarily, knowing they will not be paid for it. If they want it to reach an audience, then OA will give them an unusually wide audience at unusually low cost, without any loss of revenue, conditions that readily bring scholar consent. ${ }^{25}$

Copyright-holder consent suffices to make a commons, but it doesn't suffice to make an OA commons. This is simply because copyright-holder consent is just the legal precondition of OA, not OA itself. Works must be digitized and put online to be OA, and copyright holder consent (or public domain status) does not, unfortunately, suffice for that. Otherwise all public domain books, for example, would already be OA.

Does the removal of permission barriers suffice to make a commons? If we say that it does, then it follows that there could be a commons even in print literature -for example, public domain print literature and literature carrying the copyright holder's consent for free use. I see no problem saying this provided we distinguish the use of print literature, no matter how free, from OA, which takes advantage of the digital character and worldwide reach of the internet. In this sense, OA was physically impossible in the age of print, but a textual commons in print was not. Indeed, Ben Franklin surely believed that his idea of a free lending library was the idea of an intellectual commons, even if it was based on the firstsale doctrine and fair-use rights rather than copyright-holder consent. ${ }^{26}$

By definition, OA literature excludes no one, or at least no one with an internet connection. This is another reason why it is a commons. By contrast, non-OA electronic journals try very hard to exclude non-subscribers from reading the articles, even if nonsubscribers are welcome to browse the table of contents, abstracts, and other features. This exclusion costs the excluder money. One cost is digital rights management or DRM, the software lock that opens for authorized users and blocks access to the unauthorized. A second cost is writing and enforcing the licensing agreement that binds subscribers. A third is subscription management: keeping track of who is authorized, and performing associated tasks such as soliciting, collecting, and renewing subscribers, and maintaining their current addresses or authentication data.

One reason why OA literature is less expensive to produce than conventional literature is that it dispenses with print and publishes directly to the internet, usually from author submissions that are already in electronic form. But a second reason why OA literature is cheaper to produce is that it dispenses with DRM and subscription management - the whole infrastructure of payment and exclusion. The very feature, therefore, that makes OA literature a useful public good -its openness, or its freedom from price and permission 
barriers - is one reason why it is economically feasible. Public interest and business efficiency both support the OA commons, appealing to both altruists and bean-counters.

It's often said that no one has an incentive to maintain or improve common property, or a commons, which can lead to its deterioration. This is not true of OA literature. One reason, surely, is that most OA literature is not in the public domain and still has owners. On the other hand, the original proposition falsely assumes that the only reason to maintain property is to protect a revenue stream or some other private interest like the right of exclusion. We know this is false because it cannot explain our strong incentives for protecting public goods like air and water. Like air and water, OA literature is valuable even if it generates no revenue stream. It's very likely that this value would be protected even if the literature were not privately owned.

A good example is the way OA journal publishers take steps to ensure the long-term preservation of their articles. Both BioMed Central and the Public Library of Science deposit every one of their published articles in an OA archive beyond their control, so that the articles will not only survive, but remain OA, in case the original publisher fails, is bought out, or changes its access policies. ${ }^{27}$

OA literature removes all price barriers. It removes enough permission barriers to support all the uses customary in legitimate scholarship (essentially every use except plagiarism and misrepresentation). It removes enough access barriers to deserve to be called an intellectual commons. However, it does not remove all access barriers.

Even after we've removed price and permission barriers, there will be four kinds barrier left to overcome before we reach truly universal access. ${ }^{28}$

(1) Handicap access barriers: most web sites are not yet as accessible to handicapped users as they could be.

(2) Language barriers: most online literature is in English, or just one language, and machine translation is very weak.

(3) Filtering and censorship barriers: more and more schools, employers, and governments want to limit what you can see.

(4) Connectivity barriers: the digital divide keeps billions of people, including millions of serious scholars, offline.

\section{Tragedies of the OA commons}

OA literature is a commons because free use is pre-authorized. It's an enhanced or tragedyproof commons because it is non-rivalrous. 
The non-rivalrous character of OA literature insulates it from classical forms of the tragedy of commons, and explains why it is fundamentally unlike grazing land, Atlantic salmon, or Pennsylvania coal. But it is not proof against other tragedies. It is vulnerable, or at least apparently vulnerable, to several kinds of vicious circles.

Let's distinguish tragic depletions from what could be called tragic stalemates. A tragic depletion is the classic tragedy of the commons. The village green is overgrazed and depleted by unrestrained use. A tragic stalemate occurs when many separate individuals or organizations want to make the same decision but none wants to go first. Or, all want to follow a common plan or realize a common good, but none wants to take steps toward it before the others.

The result is not the destruction of a common good, but a paralysis that prevents otherwise motivated players from creating a common good. In a classic tragedy of depletion, individual users have an incentive to deplete, even to deplete what they agree is useful. In a tragic stalemate, individuals have an incentive to wait or delay, even to delay creating what they agree is useful. The first perversely kills what is already valuable, and the second perversely prevents something valuable from coming into being.

For example, all the merchants in a town might want a day of rest (say, on Sunday), but the first to close on Sundays will lose customers to those who do not. Before the Social Security Act was passed, many states wanted to raise taxes to provide a relief fund for the poor, but none wanted to go first, fearing that they would drive businesses out of state and attract indigents who would overburden the fund. These are cases in which early adopters fear that they will be exploited by freeloading late adopters or invite burdens that late adopters will be spared because of their lateness.

Here's a simple example. One study has shown that different players in the academy want open access, but administrators expect librarians to take the lead and librarians expect administrators to take the lead. ${ }^{29}$ Perhaps that kind of stalemate can be broken by more effective communication. But here's a more complex example that cannot. If OA spreads, then it will provide mainstream or non-academic search engines like Google and Yahoo with a larger and more useful body of content to index. As soon as they index it, they can expect to see more traffic and sell more advertising. For these reasons, it is in their interest to encourage OA and even help pay for it. There's growing evidence that they see it just this way -but none of them wants to go first. As soon as one of them pays to convert a feebased resource to $\mathrm{OA}$, then their rivals will index it at the same time. The late adopters will freeload on the early adopters and deprive them of the competitive advantage which alone might justify the investment. ${ }^{30}$

Stalemates or vicious circles are sometimes cited as objections to OA, but they are really just obstacles. They don't show that $\mathrm{OA}$ is undesirable or unattainable, merely that something desirable is more difficult to attain than we might first have thought. 
Here are three vicious circles or stalemates that affect progress toward the OA commons in research literature. ${ }^{31}$ (I'm putting each of these in the strongest terms I can, which often overstate the case; I sketch the solutions or escape routes further below.)

(1) If all or most journals were OA, then universities would save money. They would only have to pay for outgoing articles by their own faculty, not for incoming articles by faculty elsewhere. But paying for outgoing articles is a new expense. Overall, the OA system may cost less than the present subscription-based system, but universities may not have the money for the new system until the old system has withered away. In short, universities can't afford OA for their outgoing articles until they have cancelled enough conventional journals; but they can't cancel enough conventional journals until OA spreads.

During an indefinite transition period, universities or other research sponsors will have to pay for both kinds of journal. This transition cost might deter or delay the emergence of a publishing model that is not only superior for all the purposes of scholarship, but also less expensive. Here the stalemate is not universities waiting for one another, but universities waiting for OA to bring them the savings that will enable them to pay for OA.

(2) If some universities invest in the superior alternative and pay for outgoing articles, other universities can enjoy $\mathrm{OA}$ to those articles without reciprocating. Late adopters of OA can freeload on early adopters. Universities might think: "We won't make this investment, benefiting others until enough others make it, benefiting us." Universities thinking this way end up waiting for one another, paralyzing them all.

(3) Journals compete for excellent articles, and journal prestige is one of the major incentives attracting author submissions. But OA journals are generally new. Even if excellent from birth, they have not had time to acquire the prestige or impact factors of older journals, even inferior older journals. In short, new journals need prestige in order to attract excellent submissions, and need excellent submissions in order to generate prestige.

These three circles are not as vicious as they appear. Here's how to escape them.

(1') First, universities will not pay all or perhaps even most of the processing fees charged by OA journals. Many will be paid by foundations funding the research. Second, many OA journals will not charge processing fees at all. Third, many universities are not waiting for the success of $\mathrm{OA}$ in order to cancel expensive subscriptions. In the past few months alone, major cancellations have taken place at major universities (Harvard, Cornell, Duke, the University of California). ${ }^{32}$ Fourth, universities can provide OA through archiving in institutional repositories, at very little cost, long before they decide whether to provide OA through processing fees for OA journals. Finally, the transition to OA may be more expensive than a steady-state future in which OA journals predominate, but that doesn't 
mean it will be unaffordable. Universities, like other institutions, often invest money now to save money later.

(2') Freeloading late adopters enjoy OA to the literature produced by the early adopters. But early adopters are fully compensated for their early adoption, even if others do not reciprocate. They have purchased OA to the research output of their faculty, increasing the visibility and impact of the work, the authors, and the institution. Universities would not have "publish or perish" policies if they hadn't already decided that this kind of visibility and impact was in their interest.

Moreover, late adopters are punished for their late adoption. They are missing a chance to provide heightened visibility and impact to their own research output, and they are slowing the general transition to OA, prolonging the time during which they must still pay for subscriptions.

If the freeloading late adopters are institutions that produce virtually no research literature, then they are not delaying the transition to $\mathrm{OA}$ and harm no one. ${ }^{33}$

By speaking about "freeloaders" (or "free riders") I don't want to give the impression that making free use of OA literature is freeloading in any objectionable sense. This free use is exactly what the OA providers intend and desire, just as advertisers who pay for TV broadcasts welcome "freeloading" by viewers. Freeloading in the objectionable sense only occurs when someone enjoys free use who should be paying for it instead, or when free use depletes the public good. OA providers (journals and archives) only provide OA when they have some way of paying their expenses. Hence, users who enjoy the free access are not evading some obligation to pay. On the contrary, they are seizing an opportunity deliberately created by the author and helping the author's work to become known. And because OA literature is non-rivalrous, use does not deplete it.

(3') First, journal prestige is only one incentive for authors to submit their work. Circulation and impact are other incentives. OA journals have a wider circulation than any conventional journals, even the most prestigious and least expensive. Steve Lawrence was the first in a continuing series of scholars to produce evidence that by increasing audience or circulation, OA increases citation impact. ${ }^{34}$ Second, OA journals can become as prestigious as any conventional journals, even if this takes time. Some jumpstart this process by recruiting eminent editors and members of the editorial board. ${ }^{35}$ Finally, of course, we can bypass this problem entirely by converting a prestigious conventional journal to OA rather than launching a new OA journal and working to make it prestigious. $^{36}$

These methods of breaking the vicious circles probably suffice. But whether they suffice or not, we should take note of an additional method. One solution to any tragic stalemate is an external force nudging all the stalled and stymied actors into action at the same time. For example, if all the merchants in a town really do want a day of rest, and are prevented 
only by the tragic stalemate, then they would support legislation to impose a day of rest on everyone. Not only does this break the stalemate, but it wins the consent and support of all the parties "coerced" by the statute. ${ }^{37}$ Likewise, the stalemate in which the U.S. states feared to be the first to create a relief fund for the poor was one reason cited by Justice Cardozo for upholding the constitutionality of the Social Security Act, which compelled them all to act at once within a larger federal plan. ${ }^{38}$

There are several external forces that can nudge scholars into adopting the system they would prefer. One is for funding agencies to put an OA condition on their research grants, requiring grantees to provide $\mathrm{OA}$ to the results of their funded research, either through OA journals or OA archives. ${ }^{39}$ Another is for governments to require OA to all the results of taxpayer-funded research. ${ }^{40} \mathrm{~A}$ third is for promotion and tenure committees to require candidates coming up for review to provide OA to the research articles they would like the committee to consider. ${ }^{41}$

There are two ways to reconcile these strategies with the bedrock principle that OA to copyrighted works must be consensual. First, as with sabbatarian legislation, if we can show that all the parties to be bound by the requirement are consenting, then the requirement is consensual in the relevant sense. Second, research grants and university positions already carry many conditions that we enforce against grantees and employees on a contract or consent theory; by agreeing to take the grant or the job, they agree to be bound by its conditions. An OA condition would be no different. I prefer the second method to the first, because it is less susceptible to self-deception by the policy-maker, although there may be no need to choose.

Finally, note that OA literature not only resists the classical tragedy of depletion, because it is digital and non-rivalrous, ${ }^{42}$ but it also resists enclosure. Copyright holders who authorize OA by waiving certain rights could always deauthorize OA by reasserting those rights later if they wished, although I don't know of a single case in which this has happened. The author's decision to reassert her rights might be completely effective in law, if the legal status of the literature is ever tested in court. But the author has to reckon on the gap between law and compliance. At the time she decides to revoke her consent to OA, the OA edition of her work is online and contains some label or licensing language explaining that the copyright holder has consented to OA. Since OA literature may be copied and redistributed freely, chances are good that there are copies around the web, many of them unknown to the author. ${ }^{43}$ If the author revokes her consent to OA, and removes the copies she knows about, chances are good that she won't have removed them all.

This makes the revocation of consent partially ineffective. ${ }^{44}$ But above all, it gives an author a reason not even to try revocation. OA makes the enclosure of previously unenclosed content largely futile and, just as important, makes it appear largely futile. In this way, OA protects itself and intrinsically resists or deters enclosure. 


\section{The primacy of authors in achieving an OA commons}

Of all the groups that want open access to scientific and scholarly research literature, only authors are in a position to deliver it. ${ }^{45}$ There are three reasons why:

- Authors decide whether to submit their work to OA journals.

- Authors decide whether to deposit their work in OA archives.

- Authors decide whether to transfer copyright.

So even though readers, libraries, universities, foundations, and governments want OA for their own reasons, most of what they can do to promote OA takes the form of guiding, helping, or nudging authors. In this sense, authors have primacy in the campaign for $\mathrm{OA}$, and the single largest obstacle to $\mathrm{OA}$ is author inertia or omission.

Once we recognize this, we will focus on four author-centric strategies for achieving OA:

1. Educate authors about $\mathrm{OA}$

2. Help authors provide OA to their work

3. Remove disincentives for authors to provide OA to their work

4. Create incentives for authors to provide OA to their work

Let's consider these in order.

(1) Educate authors about OA

Author inertia or omission is not a sign of opposition. Usually it's a sign of ignorance or inattention. Most scientists and scholars are too preoccupied with their research to know what open access is - even today, after years of rising public recognition. This inattention harms OA, science, and the authors themselves, but it's hard to criticize directly.

Researchers are good at what they do because they are absorbed in their projects and have extraordinary talents for focusing on their work and shutting out distractions. Here we're facing a side-effect of this strength, not a simple weakness.

A March 2004 study showed that $82 \%$ of senior researchers $(4,000$ thousand in 97 countries) knew "nothing" or just "a little" about OA. Even if the numbers are better for junior faculty, we clearly have a long way to go just to educate the scientists and scholars themselves. ${ }^{46}$

A February 2004 study, however, showed that when authors do learn about OA, they support it in overwhelming majorities. ${ }^{47}$ This gives us hope that getting authors' attention will actually do some good. 
If you are a researcher, talk to your colleagues about OA. Talk them on campus and at conferences. Talk to them to them in writing through the journals and newsletters that serve your field. Talk to your students, the authors of tomorrow.

If you have provided OA to your own work, talk to your colleagues about your experience. Firsthand testimonials from trusted colleagues are much more effective than policy arguments, even good policy arguments. They are also more effective with this audience than advice from librarians or university administrators, even good advice. The chief problem is getting the attention of busy colleagues and showing them that this matters for their research impact and career. Only researchers can do this for other researchers.

A surprising number of OA converts -I'm one- didn't go beyond understanding to enthusiasm until they provided OA to their own writings and saw for themselves the signs of rising impact. There is a discernible increase in email from serious readers, inclusions in course syllabi, links from online indices, invitations to important conferences, and citations from other publications. When you experience this in your own case, it's anecdotal but compelling. When you hear it from a trusted colleague, it makes a difference.

If it's true that $5-10 \%$ of university faculty publish $80 \%$ of the articles, ${ }^{48}$ then a slight widening of the current circle of researchers who already use OA can reach a critical mass of authors.

Many scholars are not at all ignorant of OA, but say they are just too busy to take the steps to provide it for their own research articles. I'm sympathetic, but not very sympathetic. Scholars who have time to do research and write it up don't begrudge this time, because this is work they love. But if they get this far, then they always find time for follow-up steps that they do not love, such as submitting the articles to journals and responding to referee comments. Finally, they always seem to have time to bring their published articles to the attention of department chairs, deans, promotion and tenure committees, and colleagues in the field. Scholars find the time for the unloved steps in this process because they see the connection between them and career-building.

Providing OA to our work is career-building. The benefits to others are significant, but dwelling on them might have drawn attention away from the strong self-interest that authors have in OA. Get the attention of your colleagues and make this point. OA enlarges our audience and increases our impact. Anyone who takes half an hour to email an updated bibliography to the department chair or to snail-mail offprints to colleagues on other campuses should take five minutes to deposit a new article in an open-access archive or institutional repository.

(2) Help authors provide OA to their work 
Even when scholars see the connection between OA and research impact, they have to set priorities. It's not surprising that they give new research priority over enhancing the dissemination of old research, or that they give work with near deadlines priority over work with no deadlines. Here is where concrete help comes in.

Librarians can help faculty members deposit their work in an open-access, OAI-compliant archive, such as the university's institutional repository. It doesn't matter whether authors need help because they are too busy, because they are intimidated by metadata, or because their past work is voluminous or pre-digital. Librarians can help them digitize and deposit it. In most cases, student library workers can help in the same way.

Universities can help by providing the funds to pay librarians or student workers to provide this kind of help. They can help by paying the processing fees charged by OA journals when funding agencies will not do so. They can help by offering workshops on how authors can retain the rights they need to authorize OA. They can help by suggesting model language for authors to use in copyright transfer agreements.

(3) Remove disincentives for authors to provide OA to their work

When Franz Ingelfinger was the editor of the New England Journal of Medicine, he adopted a policy not to accept any article that had previously been published or publicized elsewhere. As the policy spread to other journals, it became known as the Ingelfinger Rule. It seems to be in decline nowadays, but it's hard to tell because many journals do not say explicitly on their web sites whether or not they follow the rule. The rule deters authors from depositing their preprints in OA archives, and so does uncertainty about where the rule still applies. Researchers who proudly disregard the risk that their work will offend church and state flee from the risk that preprint archiving will disqualify their work for later publication in a peer-reviewed journal.

The best way for journals to remove this disincentive is to abandon or modify the Ingelfinger Rule and to say so publicly. Journals only have to modify the rule enough to let authors take advantage of online preprint exchanges. They can still refuse to consider submissions that have been formally published elsewhere. The second best way for journals to remove this disincentive is to make their policies clear and explicit on their web sites. This will let authors make informed decisions about the risks. Authors in fields where the rule is rare, or who have no plans to submit their work to journals where it is still in force, will then have the confidence to provide OA to their preprints.

Promotion and tenure committees ( $P \& T$ committees) create a disincentive for submitting work to OA journals when they only reward work published in a certain set of high-impact journals. The problem is that most OA journals are new and don't yet have impact factors. ${ }^{49}$ When a committee makes impact factor a necessary condition for review, then it discriminates against new journals, even excellent new journals. It not only discriminates against new journals trying out a new business and distribution model, but against journals 
exploring a new research niche or methodology. The problem is not the committee's attempt to weed out the second-rate. The problem is doing it badly, with a crude criterion, so that the committee also rules out much that is first-rate.

Administrators who understand this problem can set policy for their P\&T committees. Faculty who understand this problem can volunteer to serve on the committee.

Foundations that fund research are often as blinkered as P\&T committees, even if the same foundations try to support OA through other policies. If they tend to award grants only to applicants who have published in the usual small set of high-impact journals, then they deter authors from publishing in OA journals, even while they show support by offering to pay the processing fees charged by $\mathrm{OA}$ journals.

(4) Create incentives for authors to provide OA to their work

Universities can create an incentive by requiring $\mathrm{OA}$ to all the research articles that faculty would like the P\&T committee to consider. Because this can be done through OA archives, it is compatible with publishing the same articles in conventional, subscriptionbased journals. The policy needn't limit the freedom of authors to publish in any journal that will accept their work. ${ }^{50}$

Funding agencies, public and private, can create an incentive for authors by requiring OA to the results of the funded research. ${ }^{51}$ Authors would not oppose these steps. The same February 2004 cited above ${ }^{52}$ showed that when authors are asked "how they would feel if their employer or funding body required them to deposit copies of their published articles in one or more [open-access] repositories...[t]he vast majority, even of the non-OA author group, said they would do so willingly." (Italics in original.)

Finally, we could provide a significant incentive for authors if we could make OA journals as prestigious as conventional journals of the same quality. Unfortunately, it's easier to control a journal's actual excellence than its reputed excellence. One way to boost prestige is to recruit eminent scholars to serve on the editorial board, a method used effectively by PLoS Biology and BMC's Journal of Biology. ${ }^{53}$ Another way is for eminent scholars who are beyond the reach of myopic P\&T committees to submit new, excellent work to OA journals. This will tend to break the vicious circle by which new OA journals need excellent submissions to build prestige, and need prestige to attract excellent submissions. ${ }^{54}$

\section{Contrasting perspectives on the OA commons}

Anything as large and complicated as the OA commons will inspire analysis from different points of view. 
One distinction apparent in the literature is between the standpoint of scholars and the standpoint of librarians. Scholars want OA because, as authors, they want to enlarge their audience and increase their impact, and as readers, they want free and ready access to the literature they need to keep up with their field. Librarians want OA because it will solve the serials pricing crisis, at least as far as OA extends, and it will solve a related "permission crisis" in which unbalanced copyright laws, non-negotiable licensing agreements, and software locks that often go beyond the terms of either one, prevent libraries and their patrons from making use of expensive electronic journals in the way that they could make use of print journals. ${ }^{55}$ Scholars and librarians can join forces and work toward the same end, but they rarely cite the same arguments as reasons for doing so.

Another distinction in the literature is between first-world and third-world advocacy. Researchers and governments in developing countries tend to be strong supporters of OA. ${ }^{56}$ It solves the problem of delivering access to institutions that have not been able to pay retail prices for it, and it solves the problem of making third-world research available to the first world. By contrast, first-world analysis tends to focus on the inability of even affluent institutions to buy the access needed for contemporary research, and the need of publishing scholars to reach an audience larger than the audience of affluent subscribers. Again, first-world and third-world friends of OA can join forces and work toward the same end, but they often differ in their arguments. ${ }^{57}$

A third distinction in the literature is between appeals to self-interest and appeals to the public interest. All the stakeholders -scholars, universities, libraries, learned societies, journals, publishers, foundations, and governments- have some interest in the emergence of OA, although this interest is easier to see for some stakeholders than for others. Some, like the learned societies, have just about as much interest favoring OA as opposing it. Some, like the commercial publishers, have more interest opposing OA than favoring it, but this fact often blinds us to the side of their interest favoring OA. ${ }^{58}$ Still, strong and honest arguments can be made to any stakeholder that it is in their interest to adopt OA or at least to experiment with it.

But a very different kind of advocacy focuses on normative arguments that disregard selfinterest, much as appeals to duty disregard self-interest. Authors who relinquish royalties deserve to reach their audience without a profiteering middleman standing in the way, collecting tolls. It's unfair to make taxpayers pay a second fee for access to taxpayer-funded research. Profit-seeking should not interfere with truth-seeking. Knowledge is not a commodity (just as facts are not copyrightable) and ought to be shared. Science ought to be controlled by institutions committed to the growth of knowledge, not by institutions committed to the enrichment of shareholders. Information should be free.

Finally, there is a distinction between two ways of thinking about free online access to research literature. University faculty already have free online access to the electronic journals to which their institutions subscribe. A few years ago, when faculty heard the arguments for OA, many would say, "Why is this an issue? I already have free online 
access." ${ }^{59}$ (This objection is less common today.) Let's say that researchers have a narrow interest in free access if they only care about whether they have to pay for it out of their own pocket. If their employer buys it for them, they don't care whether the employer paid a high price for it, and they don't care whether researchers without wealthy employers are left in the cold. By contrast, let's say that researchers have a wide interest in free online access if they want it to be free for everyone with an internet connection. ${ }^{60}$

Fewer and fewer faculty nowadays say that they have only the narrow interest in free access. But more and more often we hear the large commercial publishers asserting that faculty should have only the narrow interest. ${ }^{61}$

Commercial publishers can satisfy the narrow interest in free access, provided they keep their prices within reach of institutions (which they are failing to do). Why should faculty demand more? If the narrow interest covers their professional interest, and they are still not satisfied, are they not simply adding political idealism to their legitimate professional interests?

That's how Elsevier would like to frame the issue, but it doesn't work. First, we may concede that many $\mathrm{OA}$ arguments have a political or quasi-political edge. OA is not just about accelerating research and saving money; it's also about freedom from needless barriers, fairness to taxpayers, returning control of scholarship to scholars, de-enclosing a commons, and serving the under-served. But even if we disregarded these quasi-political goals and cared only about the professional needs of researchers, and we'd have to agree that the wider interest has the more enlightened view. Researchers want to see their institutions free up money from expensive journal subscriptions in order to spend it on other pressing needs, including the superior OA alternative, not to mention infrastructure, equipment, and staff.

Moreover, the narrow interest would only suffice to cover their professional interest if every library subscribed to every journal. But not even the wealthiest research library can make this claim, and the reason is the unbearable cost. ${ }^{62}$ We must move beyond the narrow interest to the wider one if only to have realistic chance of gaining access to all the research literature in our field. Finally, research advances more quickly and surely if more people are able to participate. If the lesson of open-source software is that "given enough eyeballs, all bugs are shallow" (Eric Raymond), then the analogous lesson of OA is that "given enough researchers in the loop, all research errors and omissions are shallow" -or, shallower than they would be when the pertinent literature is locked away behind price and permission barriers. To take advantage of this opportunity, we must enfranchise all who are connected -and connect all who are not.

\section{A word about Phase 2 initiatives}


Peer-reviewed research articles and their preprints are a Phase 1 problem. They are royaltyfree literature. Author donation is already a fact of life, and thanks to it author consent to $\mathrm{OA}$ is readily forthcoming. We're far from having $\mathrm{OA}$ to this entire corpus, but progress is steady and gaining momentum. ${ }^{63}$

But books, for example, are a Phase 2 problem. They generate royalties, at least if sales permit. Authors often earn nothing from research monographs, but they rarely donate them or volunteer to relinquish the chance of royalties.

One argument that might persuade authors of research monographs to consent to $\mathrm{OA}$ is that their royalties are meager at best and the benefits of $\mathrm{OA}$-enlarged audience and increased visibility and impact- are documented and significant. For most research authors below the best-selling strata, the benefits of $\mathrm{OA}$ are worth paying for, and worth at least as much as the meager royalties are likely to be. For monograph authors who understand the issues, OA can win against royalties in a cost-benefit analysis.

The National Academies Press publishes research monographs and has provided free online full-text for each of them since 1994. At the same time, it tries to sell its books in print editions. The free editions undoubtedly subtract some from the sales of the priced editions. But remarkably, they add more than they subtract. ${ }^{64}$ The Ludwig von Mises Institute follows the same practice for its research monographs, with the same results, ${ }^{65}$ and so does the Baen Free Library, for science fiction novels. ${ }^{66}$

At first this is counter-intuitive and mysterious. Aren't these plans scuttled by freeloaders who read the free editions online and never buy the print editions? The answer is that very few people are willing to read whole books online or print whole books on their home printers. Most people use free online full-text books for sampling. When they are sure that a book matches their needs and interests, they will pay for a print edition.

Amazon is banking on this theory with its new service, Search Inside the Book, ${ }^{67}$ which provides free full-text searching -but not free full-text reading- for a growing number of royalty-producing books. If free full-text searching supports sampling sufficiently well, then it will probably trigger the same net increase in sales seen by NAP and Baen, at least for the right kinds of books. Publishers are already speculating that Amazon's service will undermine sales for reference works and cookbooks, which readers will consult only for snippets, but might stimulate net sales for research monographs and novels.

The NAP, Baen, and Amazon experience suggests a second argument that might persuade authors of research monographs to consent to OA: It will stimulate a net increase in sales.

Amazon used a variation on this argument to persuade a group of commercial publishers to put their full-text books into Amazon's index. If these publishers don't lose sales, or if they gain, then the tide will have turned. More publishers will want to participate. Participating publishers will want to participate with more books. More kinds of books 
will at least be tried -out-of-print books, low-selling books, specialized market books, beautifully illustrated books, and books for which impact is more important than revenue. Some publishers will undoubtedly go beyond the Amazon experiment to the original NAP and Baen model, and try free online full-text for reading, printing, and copying, not just for searching. An intellectual commons of many kinds of OA book literature is already under way, joining the intellectual commons of OA research articles.

One important result is that OA is not limited to royalty-free literature. OA still depends on the public domain or copyright-holder consent, but we're now seeing that copyrightholder consent is compatible with royalties. This enlarges the scope of OA from the small and anomalous category of royalty-free literature to the very large, mainstream category of royalty-producing literature. Not all royalty earners will walk through the open door, but as we see more of them experiment, and more of them report greater sales or benefits that outweigh sales, then we will see more follow suit.

Books will be the first Phase 2 success, and will succeed where music and movies failed. The reason is simply that free online access to a digital music file, or movie, is all that most users want. They can enjoy it exactly as intended, either online or downloaded to the right kind of player. The prospect of reading a whole book online, or printing a whole book on one's own printer, is the ergonomic hurdle that makes all the difference. Journal articles don't face this hurdle, but they don't need to in order to win copyright-holder consent to $\mathrm{OA}$. They depend on the very different inducement that they are royalty-free and written for impact rather than income. ${ }^{68}$

One conclusion: an online, open-access intellectual commons in research literature is growing from many sources for many reasons. The incentives and economics differ from genre to genre, discipline to discipline, and decade to decade. But ever since texts have been stored in bits, which makes it possible to produce perfect copies at virtually no cost, and ever since the emergence of a global network of bit-switching machines, which makes it possible to share these copies with a worldwide audience at virtually no cost, the trajectory has always been up. There's no going back.

\section{Notes}

${ }^{1}$ For more detail on the definition of "open access", and some of the discrepancies among the published definitions, see Peter Suber, "How should we define 'open access?" SPARC Open Access Newsletter, August 2, 2004. http://www.earlham.edu/ peters/fos/newsletter/08-04-03.htm\#define 
For an introduction designed for those new to the concept, see Peter Suber, Open Access Overview. http://www.earlham.edu/ peters/fos/overview.htm

${ }^{2}$ BioMed Central and the Public Library of Science, the two largest OA publishers, both use the Creative Commons Attribution license. See <http://www.biomedcentral.com/info/about/copyright $>$ and 〈http://www.plos.org/journals/license.html>. I use the same license for my newsletter on open access; see the last lines of any recent issue, 〈http://www.earlham.edu/ peters/fos/newsletter/archive.htm>.

${ }^{3}$ Budapest Open Access Initiative http://www.soros.org/openaccess/read.shtml

${ }^{4}$ Open Archives Initiative http://www.openarchives.org/

Raym Crow, A Guide to Institutional Repository Software, Open Society Institute, version 2.0, January 2004. (A guide to the open-source software for building and maintaining OAIcompliant archives.) http://www.soros.org/openaccess/software/

${ }^{5}$ Despite the fact that peer review consists of donated time and clerical tasks, the costs are greater than most authors would guess. A recent review of the literature put the figure at $\$ 400$ per published article. One reason the figure is so high is that it covers the cost of reviewing rejected articles.

Fytton Rowland, "The peer-review process," Learned Publishing, 15, 4 (October 2002) 247258.

http: $/ /$ miranda.ingentaselect.com $/ \mathrm{vl}=4928683 / \mathrm{cl}=179 / \mathrm{nw}=1 / \mathrm{rpsv} / \mathrm{cgi}-$ bin/linker?ini=alpsp\& reqidx=/catchword/alpsp/09531513/v15n4/s2/p247

${ }^{6}$ I elaborate further on the comparison to the funding model for television and radio in "Where Does the Free Online Scholarship Movement Stand Today" Cortex, 38, 2 (April 2002) pp. 261-64.

http://www.earlham.edu/ peters/writing/cortex.htm

${ }^{7}$ The largest private funder of medical research in the United States, the Howard Hughes Medical Institute, and the largest in Britain, the Wellcome Trust, have adopted this policy. In June 2003, they and other stakeholders issued the Bethesda Statement on Open Access Publishing, calling on others to follow suit. http://www.earlham.edu/ ${ }^{\sim}$ peters/fos/bethesda.htm

${ }^{8}$ See $<$ http://www.philosophersimprint.org/>. 
${ }^{9}$ See Section 7, below for some reasons to think that some book authors could be persuaded.

${ }^{10}$ For more on the history of scientific journals and their relationship to open access, JeanClaude Guédon, "In Oldenburg's Long Shadow: Librarians, Research Scientists, Publishers, and the Control of Scientific Publishing," ARL Proceedings, May 2001. http://www.arl.org/arl/proceedings/138/guedon.html

${ }^{11}$ But see my "Open access when authors are paid," SPARC Open Access Newsletter, December 2, 2004. http://www.earlham.edu/ peters/fos/newsletter/12-02-03.htm\#payingauthors

${ }^{12}$ I discuss the connection between author donation and academic freedom in "The end for free online content?" Free Online Scholarship Newsletter, June 8, 2001. http://www.earlham.edu/ peters/fos/newsletter/06-08-01.htm

${ }^{13}$ Strong copyright protections may be part of the incentive for authors of royalty-producing genres, but not for authors of scholarly journal articles. One reason, of course, is that journal articles are royalty-free. If scholars make no income from their articles, they need no monopoly on that income in order to goad their productivity. Another reason is that scholars tend to transfer the copyright in journal articles to journal publishers (even if they could often negotiate another arrangement). The copyright in journal articles therefore tends to protect publishers, not authors. See Sam Vaknin, "Copyright and Scholarship: Interview with Peter Suber, Part I,” United Press International, February 19, 2002. http://www.upi.com/view.cfm?StoryID=15022002-015414-4119r

${ }^{14} \mathrm{~A}$ common misunderstanding among non-academics, and even some academic publishers, is that OA appeals primarily to scholarly readers, not scholarly authors. But in fact, it originated with scholarly authors looking for ways to enlarge their audience, increase their impact, and make their work more visible, more discoverable, more retrievable, more accessible, and for all these reasons useful than conventional publication allowed.

${ }^{15}$ The oldest peer-reviewed, OA journals were launched in the late 1980's. See my Timeline of the Open Access Movement, http://www.earlham.edu/ peters/fos/timeline.htm

However, the most prestigious OA journals are much more recent. One reason why prestige does not correlate with age here is that the OA movement had to incubate for a while before it was possible to recruit eminent scientists and scholars to OA journal editorial boards.

${ }^{16}$ In the United States, this is mandated by 17 USC 105. http://www.title17.com/contentStatute/chpt01/sec105.html 
Peter Veeck encountered a weird exception in which a private organization held the copyright to a publicly enacted statute and wanted to use its copyright to block Veeck's OA version of the text. See my "When public laws are in the public domain and when they are not," Free Online Scholarship Newsletter, June 25, 2001.

http://www.earlham.edu/ peters/fos/newsletter/06-25-01.htm

Also see Veeck v. Southern Building Code Congress, 5th Cir., No. 99-40632, en banc decision, June 7, 2002.

http://laws.findlaw.com/5th/9940632cv2.html

${ }^{17}$ On December 6, 2001, the French Académie des Sciences released a public statement calling on the European Commission not to apply copyright rules for royalty-producing content to scientific publications for which the authors seek no payment.

Pétition sur la Directive européenne, December 6, 2001.

http://www.revues.org/calenda/nouvelle1580.html

${ }^{18}$ For example, see Francis Muguet's “Activity Report” (October 24, 2003) on negotiations to produce a meaningful endorsement of OA at the World Summit for the Information Society. The negotiations were thwarted again and again by the common misunderstanding that all literature is royalty-producing literature. http://www.wsis-si.org/si-prepcom3-report.html

${ }^{19}$ I discuss the distinction between royalty-free and royalty-producing content, and the three phases of the OA movement, in "Not Napster for Science," SPARC Open Access Newsletter, October 2, 2003.

http://www.earlham.edu/ peters/fos/newsletter/10-02-03.htm\#notnapster

${ }^{20}$ See Section 7, below.

${ }^{21}$ When the author and copyright holder differ, then it's the copyright-holder's consent that matters for purposes of OA. OA journals typically let authors retain copyright to their articles. But conventional or subscription-based journals (non-OA journals) almost always ask authors to transfer copyright to the journal and authors almost always agree to do so.

Hence, if we want OA to the preprint (the version of an article prior to peer review), then we ask the author. Authors who deposit their preprints in OA archives typically do so before submitting their work to journals and long before transferring copyright. But if we want $\mathrm{OA}$ to the postprint (the version of an article accepted by a journal's peer-review process, often after some revision), then we must usually ask the publisher. An increasing number of journals allow authors to deposit the postprint in an OA archive. See the database of publisher policies on copyright and OA archiving maintained by Project SHERPA, 〈http://www.sherpa.ac.uk/romeo.php>. 
${ }^{22}$ Martin O. Sabo, Public Access To Science Act (HR 2613), submitted to the U.S. House of Representatives June 26, 2003. http://thomas.loc.gov/cgi-bin/query/z?c108:H.R.2613:

(The final colon is part of the URL.)

Also see my "Martin Sabo's Public Access to Science Act," SPARC Open Access Newsletter, July 4, 2003.

http://www.earlham.edu/ peters/fos/newsletter/07-04-03.htm\#sabo

${ }^{23}$ Here's an interesting exception. The Public Library of Science is a major open-access publisher. The launch of its first OA journal, PLoS Biology, on October 1, 2003, was longawaited. Many major newspapers and science journals wrote stories in anticipation of it. In the first few hours after the launch, the journal web site received over 500,000 visits and over 80,000 requests for a single article. The PLoS servers couldn't handle the traffic and crashed.

See Paul Elias, "Free online journal seeks revolution in science publishing," Associated Press, October 16, 2003.

http://www.signonsandiego.com/news/computing/20031016-1421.

openaccessscience.html

Is this a negligible exception? Or should web traffic and server load count as diminution of a common, internet resource? If so, then the internet cannot support true non-rivalrous commons, except perhaps unpopular or well-funded ones. But even when server load diminishes use for others, net-based digital commons are much more robust and less susceptible to tragic overuse than analog commons like grazing land. Moreover, the burden of overuse is temporary. When they slow down or crash, they can be restored to full service after insignificant delay.

${ }^{24}$ See Section 7, below.

${ }^{25}$ I mean that being royalty-free is a fair surrogate for copyright holder consent when we are estimating which bodies of literature will carry copyright holder consent to OA. I don't mean that we can infer consent from the fact that a work is royalty-free. (Otherwise, we could always buy consent or its equivalent by ceasing to pay authors.) On the other hand, there are ways that authors who do consent can manifest their consent so that users needn't ask them individually every time they want to go beyond fair-use. See the Budapest Open Access Initiative FAQ, "Must users ask the author (or copyright holder) for consent every time they wish to make or distribute a copy?"

http://www.earlham.edu/ peters/fos/boaifaq.htm\# consentqueries

${ }^{26}$ Because OA depends on the digital character and worldwide reach of the internet, it was physically impossible in the age of print. But how close could we come in the age of print, simply by removing permission barriers? The free lending library is one example. I learned 
the following example from Barbara McManus, an emerita classicist at the College of New Rochelle. J.A.K. Thomson, a classicist at King's College London, wrote the following in a letter to Gilbert Murray, a fellow classicist at Oxford, March 26, 1944 (p. 4). The original is in the MS. Gilbert Murray Box 174, Fols. 165-67, at Bodleian Library, Oxford.

I am concerned at the amount of good work in scholarship which has no chance of being published -unless of course the Government should subsidise it. I am pessimistic about the immediate, though not the ultimate, prospect for the Classics. I think compulsory Latin will be abolished and when that happens the Classical Departments in other places than Oxford and Cambridge will dwindle to nothing. Even now it does not pay a publisher to put out a Latin, let alone a Greek, book, however excellent, and the University Presses cannot carry the burden unsupported. But would it be possible for the B.M. [British Museum] or Oxford or Cambridge to invite really good scholars to deposit with them a typed or manuscript copy of some magnum opus on which they had spent long time and labour? It would then become available to other scholars, even if it could not be published.

${ }^{27}$ I outline several other steps taken by BMC in Lila Guterman and Peter Suber, "Colloquy on Open Access Publishing," Chronicle of Higher Education, January 29, 2004.

http://chronicle.com/colloquylive/2004/01/openaccess/

${ }^{28}$ Peter Suber, "How should we define 'open access?" SPARC Open Access Newsletter, August 2, 2004. http://www.earlham.edu/ peters/fos/newsletter/08-04-03.htm\#define

${ }^{29}$ Randall Ward, David Michaelis, Robert Murdoch, Brian Roberts, and Julia Blixrud, "Widespread academic efforts address the scholarly communication crisis: The results of a survey of academic institutions," College Ë Research Library News, June 2003.

http://www.ala.org/ala/acrl/acrlpubs/crlnews/backissues2003/june4/widespreadcademic. $\underline{\mathrm{htm}}$

${ }^{30}$ I first pointed this out in "Predictions for 2004," SPARC Open Access Newsletter, February 2, 2004 (prediction \#3).

http://www.earlham.edu/ peters/fos/newsletter/02-02-04.htm\#predictions

Shortly afterwards (March 2, 2004), Yahoo announced a program to index OA content in a more useful form that is publicly available to its rivals only in a less useful form. See the Yahoo press release. http://biz.yahoo.com/bw/040302/25391_1.html

Google is considering a similar plan to create quasi-OA that benefits itself more than its rivals. It may digitize all the public-domain books in the Stanford University library for its 
own index. Its rivals could have access to the same material only if they digitized the same works. Watch for news reports on Project Ocean.

${ }^{31}$ I talk about these and related obstacles, including other vicious circles, in "Why FOS progress has been slow," Free Online Scholarship Newsletter, May 15, 2002, http://www.earlham.edu/ peters/fos/newsletter/05-15-02.htm, and "Dissemination fees, access fees, and the double payment problem," Free Online Scholarship Newsletter, January 1, 2002, http://www.earlham.edu/ peters/fos/newsletter/01-01-02.htm.

${ }^{32}$ See my catalogue, University actions against high journal prices, http://www.earlham.edu/ peters/fos/lists.htm\#actions

${ }^{33}$ Occasionally one hears the objection that elite research universities, which produce more research articles per capita than lesser institutions, will bear the heaviest load in a future dominated by OA journals. Three quick responses: (1) Universities will not be the only payors. Foundations will pay at least as often. (2) Elite research institutions will save the most from the conversion, cancellation, or demise of conventional, subscription-based journals. (3) Elite research universities currently pay more for journals than lesser institutions, but they clearly regard this as the price of supporting a higher level of research. Do they want to say that they only buy more journals than lesser institutions because they can't persuade lesser institutions to share the cost with them?

${ }^{34}$ Steve Lawrence, "Free online availability substantially increases a paper's impact," Nature, May 31, 2001.

http://www.nature.com/nature/debates/e-access/Articles/lawrence.html

${ }^{35}$ The Electronic Society for Social Science uses the phrase "instant reputation" for success in this endeavor. See Manfredi La Manna, "The Story of ELSSS: A new model of partnership between academics and librarians," May 11, 2002, http://www.elsss.org.uk/documents/CURL 1103 02.pdf

For example, the Public Library of Science acquired instant reputation or instant prestige when it recruited Vivian Siegel to be its new Editor In Chief. Siegel was formerly the Editor of Cell. Both PLoS and BioMed Central have recruited Nobel laureates to serve on the editorial boards of their OA journals.

${ }^{36}$ A good example is Nucleic Acids Research, from Oxford University Press. NAR published for 32 years as a subscription-based journal and earned an ISI rating as one of the "hottest" journals of the decade in biology and biochemistry. After a period of OA experimentation, NAR decided in June 2004 to make a full conversion to OA, effective January 2005. http://www3.oup.co.uk/nar/special/14/default.html

${ }^{37}$ See John Stuart Mill, On Liberty, Hackett Pub. Co., 1982 (original 1859), p. 88: 
Without doubt, abstinence on one day in the week, so far as the exigencies of life permit, from the usual daily occupation...is a highly beneficial custom. And inasmuch as this custom cannot be observed without a general consent to that effect among the industrious classes, therefore, in so far as some persons by working may impose the same necessity on others, it may be allowable and right that the law should guarantee to each, the observance by others of the custom, by suspending the greater operations of industry on a particular day.

${ }^{38}$ Steward Machine Co. v. Davis, 301 U.S. 548, 588 (1937).

http://laws.findlaw.com/us/301/548.html

${ }^{39}$ I propose this in my Model Open-Access Policy for Foundation Research Grants, July 8, 2003. http://www.earlham.edu/ peters/fos/foundations.htm

${ }^{40}$ The U.S. House Appropriations Committee proposed an open-access condition for NIHfunded research on July 14, 2004. For the fate of this proposal (even after the publication date of this article), see my FAQ on the NIH open-access plan.

http://www.earlham.edu/ peters/fos/nihfaq.htm

The U.K. House of Commons Science and Technology Committee proposed an openaccess condition for all taxpayer-funded research on July 20, 2004.

http://www.publications.parliament.uk/pa/cm200304/cmselect/cmsctech/399/39902.ht $\underline{\mathrm{m}}$

I discuss these issues in "The taxpayer argument for open access", SPARC Open Access Newsletter, September 4, 2003.

http://www.earlham.edu/ peters/fos/newsletter/09-04-03.htm

${ }^{41}$ Queensland University of Technology was apparently the first university to adopt this policy (adopted September 2003 to take effect January 1, 2004).

Also see Southampton University's draft Departmental Research Self-Archiving Policy, which applies to all faculty whether or not they are under review for promotion or tenure. http://www.ecs.soton.ac.uk/ harnad/Temp/archpolnew.html

I support versions of all three of these external forces or nudges in my list, What you can do to support the cause of open access.

http://www.earlham.edu/ ${ }^{\sim}$ peters/fos/lists.htm\#do

${ }^{42}$ I don't want to give the impression that all digital and non-rivalrous commons inherently resist tragedies of depletion. For example, I believe that spam triggers a tragic depletion in the usefulness of email. If the worldwide network of email users is a commons that we are all free to graze at will, then spammers are the over-grazers that are starting to spoil it for the rest. In the case of real grazing land, the over-grazers must be a significant fraction of 
the common users. But in the case of email, spammers are tiny minority. Moreover, they only succeed in ruining the email experience for others because a tiny minority of their recipients buy their products. Insofar as spammers are to blame, the cause is greed.

Insofar as their customers are to blame, the cause is credulity. The resulting tragedy of the email commons does not deplete the content, but it does deplete the usefulness of the medium.

${ }^{43}$ See my "The many-copy problem and the many-copy solution," SPARC Open Access Newsletter, January 2, 2004.

http://www.earlham.edu/ peters/fos/newsletter/01-02-04.htm\#manycopy

${ }^{44}$ Or, to be more precise: since OA to copyrighted content must be consensual, revoking consent to $\mathrm{OA}$ is fully effective in negating the status of OA. But it could be completely ineffective at introducing access barriers to that content.

${ }^{45}$ Versions of Section 5 have appeared earlier as "It's the authors, stupid!" in SPARC Open Access Newsletter, June 2, 2004, <http://www.earlham.edu/ peters/fos/newsletter/06-0204.htm\#authors>, and "The Primacy of Authors in Achieving Open Access," in Nature, June 10, 2004, <http://www.nature.com/nature/focus/accessdebate/24.html>.

${ }^{46}$ Ian Rowlands, Dave Nichols, and Paul Huntingdon, Scholarly Communication in the Digital Environment: What Do Authors Want? CIBER, March 18, 2004.

http://ciber.soi.city.ac.uk/ciber-pa-report.pdf

${ }^{47}$ Alma Swan and Sheridan Brown, JISC/OSI Journal Authors Survey Report, Key Perspectives Ltd., February 2004.

http://www.jisc.ac.uk/uploaded documents/JISCOAreport1.pdf

${ }^{48}$ I've heard this estimate from several sources but so far without documentation. I don't vouch for the numbers. But the true numbers will very likely be close to these.

${ }^{49}$ However, some OA journals are old enough to have impact factors. A study by Thomson ISI showed that these were comparable to the impact factors of conventional journals. See James Testa and Marie E. McVeigh, "The Impact of Open Access Journals," Thomson ISI, April 15, 2004. Here's an excerpt from the study: "These journals all adhere to high publishing standards, are peer reviewed comparably to other journals in their respective fields, and are cited at a level that indicates they compete favorably with similar journals in their field. The chief difference between these and some other journals covered by ISI is that the entire content of the OA journals is available without cost to the user." http://www.isinet.com/media/presentrep/acropdf/impact-oa-journals.pdf

${ }^{50}$ For more on this policy, see endnote 41 , above.

${ }^{51}$ For more on this policy, see endnote 40 , above. 
${ }^{52}$ See endnote 47, above.

${ }^{53}$ See endnote 35 , above.

${ }^{54}$ See Section 4 for more discussion of this vicious circle.

${ }^{55}$ I discuss the two standpoints, and elaborate on the library's standpoint, in "Removing the Barriers to Research: An Introduction to Open Access for Librarians," College $\mathbb{E}$ Research Libraries News, 64 (February 2003) pp. 92-94, 113. http://www.earlham.edu/ peters/writing/acrl.htm

${ }^{56}$ See for example Bioline $\langle\underline{\text { http:}}: / /$ www.bioline.org.br/ $>$, the Electronic Publishing Trust for Development $\langle$ http://www.epublishingtrust.org/ $>$, the International Network for the Availability of Scientific Publications <http://www.inasp.info/>, SciDev.Net <http://www.scidev.net/>, and and SciELO <http://www.scielo.br/>.

${ }^{57}$ Many journal publishers donate electronic subscriptions to third-world research institutions. See Ann Okerson's list of such programs, $<$ http://www.library.yale.edu/ 1license/develop.shtml>. But this creates another reason why north and south friends of OA use different arguments in their analysis and advocacy. A major issue for developing countries is whether these donated subscriptions to toll-access journals are good enough, or whether researchers must press for true OA.

${ }^{58}$ Here are two examples of publisher self-interest favoring OA. (1) Commercial publishers have raised subscription prices four times faster than inflation since 1986. It was inevitable that this could not continue forever. Starting and late 2003 and continuing through the present, more and more libraries are making the courageous but painful decision to cancel important journals rather than pay another price increase. On January 7, 2004, the University of California Academic Senate and all the library directors of the UC campuses said in a public letter, "The economics of scholarly journal publishing are incontrovertibly unsustainable.” See

〈http://libraries.universityofcalifornia.edu/news/facmemoscholcomm 010704.pdf $>$. The letter was referring to conventional, subscription-based journals, not OA journals. It is now in the self-interest of commercial publishers to experiment with OA because they cannot continue business as usual. (2) Publishers that have digitized the back run of a journal can make a trickle of income by selling access to it. But more and more journals will discover that providing $\mathrm{OA}$ to the back run will bring more net gain than the revenue. It will increase the visibility and impact of the journal, and its 'brand', which any competent journal can translate into advantage in the competition for submissions, advertising, and subscriptions. (3) Learned societies and non-profit organizations that publish journals often want to charge subscription fees and generate revenue, but they may have more to fear from the giant commercial publishers, whose "big deals" soak up disproportionate shares of library budgets, than they do from OA. 
${ }^{59} \mathrm{I}$ heard this often myself. Bob Parks heard it often too and describes his observations in "The Faustian Grip of Academic Publishing," a preprint posted to WoPEc (Working Papers in Economics), July 2001.

http://econwpa.wustl.edu:8089/eps/mic/papers/0202/0202005.pdf

Parks: "The point is that readers do not necessarily want [free online journals], especially if they can have [priced journals] without giving up their office or phone or secretarial services....Readers do care about free availability. But will they demand [free online journals] versus [priced journals]? Free availability to readers is no out-of-pocket costs." Parks is describing the view of others, not necessarily his own.

${ }^{60} \mathrm{I}$ discuss this distinction in more detail in "Elsevier CEO on the Public Library of Science," Free Online Scholarship Newsletter, February 6, 2002. http://www.earlham.edu/ peters/fos/newsletter/02-06-02.htm

${ }^{61}$ When Derk Haank was CEO of Reed Elsevier, he made this argument in an interview in Information Today. See Dick Kaser, "Ghost in a Bottle," Information Today, February 2002, $<$ http://www.infotoday.com/it/feb02/kaser.htm>. It has been a favorite Elsevier argument ever since.

${ }^{62}$ I discuss some measurements showing the journal gaps at leading U.S. research libraries in "What's the ullage of your library?" SPARC Open Access Newsletter, January 2, 2004. http://www.earlham.edu/ peters/fos/newsletter/01-02-04.htm\#ullage

${ }^{63}$ See for example my account of the progress of OA last year, "Open Access in 2003," SPARC Open Access Newsletter, January 2, 2004. http://www.earlham.edu/ peters/fos/newsletter/01-02-04.htm

${ }^{64}$ See Michael Jenson, "Academic Press Gives Away Its Secrets," Chronicle of Higher Education, September 14, 2001. Jensen is the Director of Publishing Technologies at the NAP. http://chronicle.com/prm/weekly/v48/i03/03b02401.htm

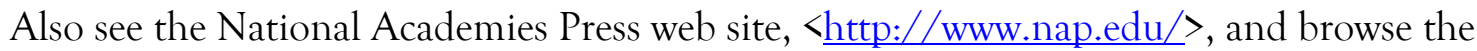
free full-text books.

${ }^{65}$ Jeffrey Tucker, "Why We Put Books Online," March 12, 2004, posting to the Ludwig von Mises Institute blog, $\langle$ http://www.mises.org/blog/archives/why we put books online 001698.asp>, later turned into an article, "Books, Online and Off," Ludwig von Mises Institute, March 22, 2004, 〈http://www.mises.org/fullstory.asp?control=1473 > . 
${ }^{66}$ Baen Free Library, <http://www.baen.com/library/>. Also see Eric Flint's explanation of Baen's business model and success, "Prime Palaver \#6," April 15, 2002, <http://www.baen.com/library/palaver6.htm>.

${ }^{67}$ See the Amazon press release, $<$ http://phx.corporateir.net/phoenix.zhtml? $c=97664 \& p=I R O L-N e w s T e x t \& t=R e g u l a r \& i d=462057 \&>$, October 23, 2003, and FAQ, <http://www.amazon.com/exec/obidos/tg/browse/-/10197041/0022808347-4161631>. The service itself has no particular URL; it is integrated into the entire book portion of the Amazon site. 